\title{
Tactics and Vertical Fire
}

\section{Lieut.-General von Sauer \& Captain E. H. Bethell R.E.}

To cite this article: Lieut.-General von Sauer \& Captain E. H. Bethell R.E. (1891) Tactics and Vertical Fire, Royal United Services Institution. Journal, 35:155, 71-83, DOI: 10.1080/03071849109417258

To link to this article: http://dx.doi.org/10.1080/03071849109417258

\section{Published online: 11 Sep 2009.}

Submit your article to this journal

Џلl Article views: 4

Q View related articles $\sqsubset$ 


\title{
TACTICS AND VERTICAI, FIRE.
}

\author{
A Winter Lecture delivered to the Officers of the Fortress of Ingolstadt. \\ By Lieut.-General vos Siuer.
}

(Translated by permission from the German by Captain F. H. Betneld, R.E., Irrigade-MIajor, R.E., in Ireland.)

N.B.-In the following translation the terms. "gun-fire" or "horizontat fire "are contrasted with the term "vertical fre," which means the fire of mortars and howitzers; and the clunsy term "vertical fire piece" is generic, includes mortars and howitzers, and is contrasted with the term "gun."

Gextleyex,-You had the goodness last year to give your kind attention to my views about shortened methods of attack on fortresses and their repulse. This encournges ine to speak to you to-day about a question which lies nearer to all of us than fortress warfare.

This question is the battle of the future, and, therefore, includes both attack and defence, and I shall address myself especially to the manner of conducting the attack and the defence in the battle of the future.

I willingly confess that the inmediate motive for my present address has been furnished by another tactical treatise which has made a deep impression, not only in your own, but also in the willest circles. I allude to the valuable work of DIajor Keim, Battalion Commander in No. 136 Infantry Reginent, which contains the substance of a lecture delivered to the Military Society in Berlin, and which the "Militïr. Wochenblatt" has printed in the Ist Beiheft of the current year."

The name of it is "The Present State of Tactical Science and Battle Training."

During the perusal of this I felt that, in spite of the opposite intention of the author, the deduction that the defence had become the stronger form of battle wight be drawn from Kein's arguments. Tho recent essays have borme me out here; they appeared in No. 13, and Nos. 17 to 20 of the "Militiir. Wochenblatt" of 1890. One is called "The Improvement in Armaments and the Offensive," and the other "Tactical Examples from 1859 to 1890 , with special reference to Infantry"."

The authors of these two treatises have certainly felt as I did, and have thruwn their weight into the scale to liclp to restore the attack to its rights as a well-considered form of battle. The circumstance that neither Major Keim nor the writer of the essay No. 13 of the "Mlilitär. Wochenblatt" vention a weapon, on the effects of which I should wish to base my deductions, chiefly animates me with a desire to throw my veight into the same scale. The allusion to this weapon in the abore-mentioned "Tactical Exanuples" is in agreenent with my views, but the essay does not go far into the subject.

\footnotetext{
I tranglation of this by Mrajor W. Sanger appeared in the Occaional Notes in 5o. 152 of the Journal.
} 
The weapon is vertical fire. The "Tactical Examples" say of it: "The idea that vertical fire is wanted elsewhere than with siege artillery may be considered as established ;" and add : "the Russian Army possessc.s already complete field mortar regiments, and light mortars, for taking intos the field, will soon be ready almost everywhere." The latest innovition in Austria, too, as we know, lias been completed by the establishment of mortarfield batteries, and you yourselves have secn mobile nortar batteries take part in field manouvres. Therefore, the artilleryman may take Keim's Worls, "Most tactical books are written by infantry men,", as a liearty" invitation to him to supplement and complete them. 'This attempt is furtheijustified, because Keim's requirements that "the infantry Olticers should make thenselves better acquainted with the fire effect of artillery, and industriously visit the practice.ground, so as to kee with their own eyes what the effect of artillery is, and to estimate its effect in lattle," has not, so far, been fulfilled. It is needless to say we shall be glad to see this suggestion carried out.

If we follow the particular manner in which the artillery lias been developed in the last 300 years, we must allow that it would be nuch hardernow for the infautry Officer to get a sufficient tactical illustration of the fire effect of artillery than it was in the days of smooth-bores. All who, in those days, visited a practice-ground learnt there nearly all the trade secrets of the disciples of Barbara, and saw how guns and howitzers (that is horizontal and rertical fire pieces), placed together in the same battery, could be used. Apart from the consideration that this is now only possible to a limited extent, we liave to reckon with the fact that field guns and vertical fire pieces belong to two different hinds of artillery, of which we can by no means assert that they are connected in the same way as are heary and light cavalry.

The circumstance that modem field artillery knows nothing but flat trajectory guns has led to the general onission from tactical tenching of a kind of artillery fire which field batteries now no longer have at theirdisposal. .

The times change, and we change with them. Thirty years have now elapsed since the list smooth-bore gun was introduced into the field artillery. It was a light 12-pounder, which was taken to the war of 1866 , but its performance did not at all come up to the expectations formed of it, and it rery soon had to give way to rifled guns. But he who can carry his thoughts back so far will remenber the advantages which were boasted for that fieldpiece, copied as it was from the French "Canon obusier Napoleon."

There were voices that prophesied for it a greater future, at least for field service, than for the rifled guns; and what was it that was specially praised in the 12-pounder? That it fired horizontally and vertically:

Slight as was the accuricy with which it fired verticnlly, it gnve more chance of hitting than did the smooth-bore howitzer, and this was recognized as an inprovement to be thankful for. If at that time rifled howitzers had been introduced, with rifled guns, would the idea have been formed that. tactics could dispense with vertical fire I If we doubt that fast, we may on the other hand accept this : that the entirely seprarate lines on which guns and vertical fire pieces have been developed must necessarily lead us to many kinds of tactical errors; to eliminate which we must take immediate action, because the rertical fire piece has reached an equality witl guns in general, and with ficld guns in particular.

Our fathers knew what they wanted howitzers for in the field, and we, too, must learn to find out the help which the vertical fire piece may afford, not. only before positions in position and fortress war, but also against positions: in field war. 
As you know, vertical fire in the time of spherical projectiles was the onlyIneaus of firing hollow projectiles; the effect of these was then considered (especially the moral effect) so decisive that there was no doubt about adopting them, even alone with the slowness and clumsiness attendant at that time on shell fire, which was then remarkable for its inaccuracy and its short range.

With the introduction of rifled guns, the advantage credited to the abovenamed 12-pounder was attained, viz., that horizontal fire guns fired shells. By this means a particularly highly valued and entirely peculiar quality of vertical fire became common to guins also; but the guns being rifled, had the alditional advantage of more accuracy and greater muge than the smoothbore mortars and howitzers. Thus it is casily explained why it was sought to replace the slow vertical fire-at all events for battle-by the gun-firel shell. The attempt was first made to provide the rifled guns with diminishel charges, so as to be able to use not only horizontal but also vertical fire, as liad been done with the 12-pounder; but the result was about the same in this case as with the 12-pounder.

It is natural that a gun should answer only one object well, and any secondary object indifferently. If it is decided to renounce neither, then both will suffer, and thus it happened in our case. If the twist of the rifling was right for high charges, it could not possibly be sufficient for low charges, if the fuze was made right for the shock of a great charge, then, sometimes, shells did not explode with the small charge. Hence, we cannot ronderthat, with us, it was soon decided to ain at the perfection of one object, and to leave the attainment of the others to the future. It is eyually comprehensible that good gun shooting, as being the object required to be attained in the first line, was aimed at and vertical fire left alone, for the actual battlefield fire will always remain flat trajectory fire. Here we may blane the arrangements of France and Austria, who kept the diminislied charge for field pieces, while we kept then only for a few old fortress guns.

Many people held to the opinion that, however great relocity was given to the field guns, they could still be used with sufficient success for position warfare, and that shrapnel would, at least, make it dangerous for an cnenybehind good cover. It is especially noticeable that on this point the anthor. of the "Tactical Examples" of the "Drilitiir Wochenblatt" feels himself compelled to speak as follows: "The doubts whether the improved shrapnel conld succeed against earthworks, which were first raised after 1878 (but not by the artillery), were at first rather lostily decided against, but were afterwards considered justified." We, too, must acknowledge that these doubts are justified, and must add the necessary consequence of this confession; for, however nany ways of improving guns are arrived at, there must alway's be two points on which horizontal fire wust be beaten by vertical fire, viz., the steep angle of fall of the shell and its fragments, and the possibility of having the hostile mark under fire from entirely unseen positions.

Shells and shrapnel fired from guns, too, are effective by their burst and splinters, but this effect is different from the effect of burst of shells in vertical fire. I Iet us assume that the shcll from a gum reaches the mark witl a terminal velocity of 900 to 1,200 feet, then it is demonstrable that both fragments and base of the shell will move forward towarcls the mark at that velocity. Thus we get depth of effect towards the front, but a very moderate effect in width; and this quality of the effect of gun-fired shrapnel must become more marked as the trajectory is flatter. It is exactly on this depth of effect that the artillery rightly lay much stress. Even the use of high explosive bursting charges will not turn this "deep" effect into an all-round effect until the explosion is strong enough to give the fragments of the shell a much higher velocity than the terminal velocity of the shell. Artillery- 
men, however, recognize that it is harder to get a decided superiority of velocity from the burst over terninal velocity, in proportion as the latter is higher and the bursting charge smaller; but it is exactly these two qualities (high velocity and small space for bursting clarge) which we find in the shells of field guns.

In vertical tire it is otherwise. Iere the velocities are swall, and the shot themselves-and, therefore, their internal contents and bursting chargeslarger; hence there is no difficulty, especially when high explosives are used, in devcloping bursting velocities much higher than the terminal velocities of the shells. This, and the steeper angle of descent of the shell, constitute the great difference between horizontal and vertical fire.

Now consider the case of a mortar (or howitzer) sleell, just as we did of the shrapnel shell, at the end of its flight, but before it touches the ground, and therefore a few yards from its goal; the shell is filled with a high explosive, and is exploded by a time fuze; in this case you do not, indeed, get a very "deep" splinter effect, but you get instead of it a very" murderous all-round effect, which can only be compared to a destructive hail.

Against the perfectly vertical fall of most of these iron hailstoncs, no breistwork gives any protection. A body of men under such fire call only escape it by a change of position, and we must further observe that the same shell charged with a high explosive can penetrate every head corer which in field warfare can be opposed to the action of its burst.

But not only has the destructive force of modern vertical fire become altogether extrnordinary, but also its range is so little inferior to that of guns, that the inferiority makes no odds in battle, while its accuracy at the decisive ranges, from 1,500 to 2,000 yards, is rather superior than inferior to that of guns.

Regarding the complaint that used to be made in the days of spherical projectiles of the slouness of vertical fire, it may be observed that Griuson's works already produce a 12-cm. (4-7-inch) howitzer for ficld serrice which can fire twenty shots a winute with very good effect.

I may here obserre that the solution of the question of quick fire for guns is sensibly. cliecked by the fact that it is indispensable to check the recoil completely.

This requisite is, on account of the inferior velocity of the shot, more easily satisfied with howitzers than with guns, with which latter more rapid fire remains inseparable from diminution of calibre.

Modern armament having at its disposal pieces for vertical fire perfectly suited for the field, both howitzers and ruortars, perhaps I may, with reference to the difference between these two, adduce the fact that the service and handling of howitzers approaches wore nearly to that of gums than the service of nortars does, that mortars, on the other hand, may often be more completely removed from the enemy's sight than howitzers, and, above all, that they have steeper angles of fall than these. On the other hand, howitzers can, if necessary, deliver a fire with a sowewhat flattertrajectory than mortirs, and can therefore defend themselves better. IIowitzers for field use are seldom of larger calibre than $12 \mathrm{~cm}$. ( 4.7 inches), with which calibre they are to be classitied for weight and mobility with field guns, but can in the same space carry only half the ammunition that the guns can.

Field mortars, of that you have convinced yourselves already, can be classed as suitable for the field up to $15 \mathrm{~cm}$. calibre, but again.can only carry half the ammunition the $12 \mathrm{~cm}$. howitzers: can carry: The decision for one sort of piece or the : other must depend on whether more reliable 
mobility and easier ammunition supply is more important than great pene. tration and explosive effect. If we believe that the enemy, even in the field, must above all be destroyed in his casemates and with them, and if the resistance of these is reckoned nearly as high as that of provisional and permanent fortifications, then the larger calibres will hardly be left behind; if, on the other hand, we think it sutficient to hit the unhidden eneuy, and if we consider the strength of field casemates unimportant and systenlatic bombardment of unseen casemates too wasteful of time and ammunition, then we shall prefer the swaller bores. These are questions which must be decided by trial and experience, and the decision will depend generally ou what is the smallest bore which is fully sufficient to effect the purpose in view. But for the purposes of tactical instruction these considerntions affect us much less than does the difference that exists between horizontal and vertical fire. When a vertical fire battery fires out of a glade in a wood, or behind the crest of a hill, it remains, especially with smokeless pouder, entirely hidden from the enemy ; but it cannot possibly see the effect of its own shots from its position. Thus the shooting for range of the batteryand its fire in general must be directed and watched from a point which affords a complete view of the mark which is to be shot at. It is very conceivable that a small field telegraph may be required in order to transmit the orders as quickly as possible to the battery. It is also conceivable that the battery will sometines find it most simple to take its direction of fire from the compass, and if you remember that the tine of flight of a shell is as much as a quarter and even half a minute, then you will see that the shooting for range can only in exceptional cases be done as quickly as that of a gun battery. That, however, does not prevent the rapidity of firc being very quick when once the right position of the trajectory las been found ; this will be rendered easier for vertical fire by the larger bursting charge and consequent smoke cloud of its shell, by its sharper angle of fall and lower velocity, and above all by the earthworks of the cuemy. It is just these field-parapets that show themselves by the fresh heaps of earth against the background of the ficlds, and there is seldom in these cases tine to provide good masks. But bad masks often serve to show up well what they are meant to hide. Miasks, noreover; injuriously affect one's own feld of fire, and it is the defender who wants this most. In proportion as he allows due weight to this consideration, his position must become more visible to the eneny. Against the horizontal fire of the attack this natters little, unless it takes any of the trenches in flaok; but with rertical fire it is quite different. Nothing can assist the trial shots for range in the latter case more than a clearly visible breastwork, or any visible heap of earth; and nothing will more entirely demoralize the men bidden behind this cover than crushing proof of the uselessness, even the harmfulness, of their laboriously erected cover.

But the effect of even good masks in increasing the difliculty of the trial shooting, and the destructive effect of the hail of vertical fire is much less than their effect in misleading and injuriously affecting horizontal fire from guns, and the latter can by no means produce the dinniaging results agrinst. poods and localities, and above all against their hedges and enceintes, which vertical fire produces.

You see frou this that we shall in the future lave to do with quite another vertical fire than that of the time of spherical projectiles. For the attempt made in old times, in fortress warfare at least, to produce a hail of splinters with the bursting of the shell, by cutting of their fuzes short, may be compared with the result aimed at under modern ballistic conditions, modern fuzes and high explosive bursting charges, in the same way as the arquebus may be compared to the infantry rifle of 1888 .

Thus in the present rertical fre we possess really an entirely new but nono 
the less decisive weapon, and that weapon, gentlemen, has, in my opinion, been placed at our clisposal just at the right and most important time tib remove the doubts as to the superiority of attack with which the small calibre rifle and smokeless powder invade us.

As all tacticians, iucluding Keim and even $v$. der Golz, in his "independent patrols" recommend to the defender the greatest possible use of the spade; as the horizontal fire of field artillery, either with shell or shrapnel, cunnot drive the enemy out of his position, nor yet sufficiently. shatter hin in it, to allow the attacking infantry to advance against the hostile lines without overwhelning losses, I ask you whether we do not give ner life to the attack by providing it with a wapon which enables it to be confident of striking the enemy most sensibly exactly where he has thought himself strongest.

Let hin fortify himself to his henrt's content, the more he does so, according to known metheds, the more surely will the iron splinter hail of the attack unite over his supjorting points. But where this is the case, there is only one thing to do, and that is to evacuate the position which becomes: otherwise an inevitable grave. If the defender has prepared himself field casemates and dramn back into them, then, whether or not he is shattered with them, I hold that the infantry will always think the artillery has done it good service in compelling the enemy to retire into the doubtful shelter of the casenates.

The enemy who in the old days withdrew from the shot-torn parapet into the blockhouse that servel as reduit, or into some similar shelter, was as much to be feared in this as he was before at the panapet, and likewise the defender who sat at the foot of the hreastwork and saw almost the whole artillery fire of the enemy whistle harmlessly over his head, but who stool up directly it ceased, and overwhelned the appronching enemy at the best ranges with his mpid fire. But to-day the question is another. What are now built for blindages and casemates are no longer defensible buildings. 'They are arrangements for shelter, which must be left if the position is to be defended. Now it is impossible on account of vertical fire to await the storn at the foot of the interior slope, and if this waiting must be in casemates. and such like structures, then I will suggest for consideration this questionWhat is there to guarantee the certainty that these casemates will be quickly enough exchanged again for the fire-line when the latter has to be held?

- I have already (a propos of my "Sketches of Shortened Fortress Attack ") spoken so clearly on this point, that $I$ should be afraid of wearying you with repetitions if I tried to recur to the simple possibility of wearing the enemyout by false attacks whenever he retired into his shelter. On the other hand, I ought to remind you that the defender, whom moden vertical fire compels to retire under his Lomb-proofs, takes with him to his cellar-like abode ideas of this fire which are as demoralizing to him as they are cucoumaging to the attack.

If you have to allow that up till now the attack possessed no means of surely bringing about that discouragement in the enemy; then you will agree that modurn vertical fire is a very inportant addition to the strength of the attack. But the strength of this support is enliunced by the fact that the vertical fire accompanies the advancing infantry up to the threshold of the place which is to be assuulted, and thus, if the eneny has left his slielter, can keep him down as no other weapon can.

As long as powiler-smoke interrupted the view, one might have been anxious as to how far the artillery support could go on; but now no smoke hides the lines of the defenders nor the advancing lines of the attack. Thus there is no clanger for the latter while the former are themselves a nark. We may further add that the vertical fire of separate vertical batteries is 
wuchi casier to watch than the flat trajectory fire of a great field artillery position. Now the adrance of the infantry has always been supported by artillery fire up to the present date, but in order to afford this support affectively, it nas often necessary for the field artillery to linber up and accompany the infantry attack. You know that this procecding of the field artillery involved not only the temporary interruption of its fre just at the moment when it was most wanted, but, also (and this, too, you know), this impetuons adrance involved losses, which turned the result which it helped to gain into a very Pyrrhus' victory.

The nearer the small-bore rifle and the depth of effect of field artillery lave brouglit us to this danger, the more welcome will be the support to the attack of vertical fire, which necessitates neither a cliange of position for the battery using it nor a panse in its fire, but which could support an advance of the tield artillery, if this were necessary, in a manner not hitherto possible. Horeover, it is quite conceivable that it might require effective vertical fire to cnable the feld artillery to take up the position required.

If the artillery of the defence is favourably placed itself and strong enough to keep the attacking artillery from every favourable position, will not the latter willingly remember the demon power it possesses in its vertical fire? As soon as it uses this aright, the horizontal fire of the defence will not cause it any anxiety, for an inferior number of vertical fire batteries will suffice to keep down, tactically, the stateliest array of hostile field guns. These latter are utterly unprotected against the vertical fire batteries, and while the guns must be placed so as to have a clear field of fire, and, therefore, be exposed to view, they cannut touch a hair of the heads of the well-covered vertical fire bntteries; for this dangerous enemy of horizontal fire can only be fought by vertical fire. This would not be easy if the vertical fire piece were compelled to gire itsclf away to the gun by exposing itself; then it would be, :unyhow, a question of straight shooting, and it rould depend on that whether the vertical fire battery wass silenced by the guns or vice rersi. But what inducement is there for the verticnl fire battery to expose itself to the gun fire? It is at once indifferent to the former whether it fires straight against the wark or obliquely, and whether it stands higher or lower than the ruark. It is the only kind of artillery which can fire away orer its own field batteries and other troops without the least inconvenience. It never draws the enemy's fire on the troops in frout of it, because, on account of smokeless powder, the enemy can neither see its fire at all nor by means of it descry its position.

It maty, in so far as its range pernits, fire from one wing of the battlefield agaiust a mark in the middle of it and vice versî; it does not sensibly cramp any other troops in space for movement or position, as the only question for the troops would be whether to place themselves in front of it or behind it when il came under effective fire. Is it any very great feat so to place a vertical fire battery (provided it has sufficient mobility) 1,500 or 2,500 yards from the defender, as not to be visible by him, and, therefore, so as not to come under the fire of his guns? In answer to this question I may remind you that I gave you the opportunity last year of convincing yourselves how easily vertical fire batteries, even in broad daylight, and with a faultless cutpost systen arranged for the purpose, could be brought up even to fortresses and open fire.

It is exactly this porrer of corered appronch and this invulnerability by horizontal fire, on which the very marked superiority of vertical fire rests.

Even if we assume that field artillery succeeded by means of high-explosive bursting charges in getting good results against troops behind visible breastworks and such like earthworks, we must never forget that these field batteries remain exposed to the fire of the enemy's feld batteries and of his 
rertical fire batteries. I must also claim for vertical fire the advanitago that it can not only prepare the attack in a most relinble way, but that, if the attack is repulsed, it cin take the retreat under the wing of its effective pro. tection.

If the vertical fire battery need not cease its destructive ire until the attacked had got within a couple of hundred yards of the enemy, and if a repulse then took place, there would be nothing to prevent the battery firing again at the original mark directly the attacking troops had retired those few hundred yards. This kind of support you can only give by fire with a steep angle of descent, and if the defender has a just iden of it, it will scarcely stimulate his powers of resistunce.

With this iden of the tactical use of vertical fire, I take up, no doubt, a somewhat different standpoint from that assuned, for instance, by the anthor of the essay" (undoubtedly a thoroughly competent writer) on "specinl batteries of the field army;" which you received with the volume of the "Year Book for the German Army and Navy," issued last January.

In this valuable essay it is proposed not to allow the vertical fire batteries to come into action except as special batteries, outsile the frame of the field army. These detached batteries, then, are not to be used for the general purposes of the artillery, but exclusively for the following object, viz., "immediately before the decisive attack to keep the part of the position where the attack is to break in, and its supporting points, under a well-considered fire, a fire which shall guamntee suceess, durintr which the attacking lines will splureach as near as possible to the enemy's position, and towards the end of which the final assanlt will be made." Then, further on, it says that "the opening of the vertical fire should not take place till the hours that have passed have drawn the picture of the battle in sharper outline, and when nothing is to be expected that could justify a cessntion of the vertical fire, when it had ouce begun." "Thus the object of the special batteries is fulfilled when the moment arrives for assault, whether success crown it or not. The rotle the vertical fire batteries have to play is finally compared to that of the great batteries of Napoleonic tactics ; for it is said that these correspond exactly" in their object and value to the special lastteries. Let us hope that in a future war they will gain as great successes as did those. I do not wish to diminish that confident hope when I say, that between the great batteries of Napoleon and the special batteries described here there are practical differences, and that those differences are in respect of their tactical use.

Those great batteries were the same approximately as what we nowadays call the corps artillery. They were, therefore, part and parcel of the field artillery, and, as we know, were then divided into light and henvy batteries, of which the latter had the 12-pounders; the first, the 6-pound gun, and both had the 7-pounder or 15-cm. howitzer.

Now Napoleon at any rate had no idea of placing his vertical firing pieces together in separate batteries, and only using them when the last decisive moment mas imminent. The heavy batteries, which, on account of their weight, moved something slower than the light batteries, showed the enemy, by their louder sound, that now they too had come on the ground and had joined in at the right point to supply the euergy still wanting to make the last resistance yield. Here it was not a question of the relation of tactics to vertical fire, but only of a reinforcement of gun fire generally just as reinforcement of infantry fire is the rule for the last preparation for the assault. To carry out this reinforcement with the proposed special batteries alone, at any rate, would only be possible when the attacking artillery had been able to cope with the enemy's field guns. But this can only be expected in the rarest cases, for not only will the favourable deployment of the field guns of the attack be hindered by those of the defence, but also 
the guns will be opposed in a yet more energetic way (and of that I should like to speak more fully) by the vertical fire of the defence.

If the defence has howitzers or mortars, then uncloubtedly it will be in a position to keep down the whole horizontal artillery fre of the attask thoroughly and to make all support of the attacking infantry by the guns extremely doubtful. How under these circumstances does it fare with the requirement of the "tactical examples," according to which the advance of the attack has tied to it the condition that "the attack has succeded in breaking down the artillery of the defence, and in concentrating, with what artillery remnins over from the duel, on the hostile infantry " ?

In the discussion on "special" batteries it is true the author says, that the proposals adrocated allow the defenders to make the most extensive use of vertical fire from unseen positions; but, he says, "that that is only an apparent advantage, for that all its successes conld not be decisire, if the attacking troops use their power of free movement, change of position, and make skilful use of the ground, while the fighting power (i.e., the ammunition) of the defensive 'special' batteries is meankhile gradually consumed and is nearly exhausted at the moment when the attacker's vertical firc watteries appear on the scene. I have not brought this theory before you in order to discuss it thorounhly, but I should like to put this one question concerning it: how is the field artillery of the attack by free movement and change of position to slelter itself from the vertical fire of the defence?" An army corps has roughly 100 gums; are they to gallop about the battlefield, up and dorrn, to escape the enemy's vertical fire? Or are they by skilful usc of the ground to choose positions where they will be concealed from it ? Wow will they be able from such positions to engage the enemy's field artillery ? And if they fail to do this what sort of a look out will it be for the free movement of the infantry?

I think these fow hints serve to show the difference there is between an active and effective support of the attack and the task for which in the "Year Book," a special battery is required for ench army corps. The "Year Jook" remarks that this addition depends on the proceedings of other nations ; that where, as in Russin and dustria, vertical fire batteries had been formed on an cxtensive scale, there could be no longer any question of "special" batteries, but only of heavy hatteries of field artillery, to which the principles cstablished for the "special" batteries would not apply; it continues: "Then with one word a light but mobile field artillery would have become effective but helpless, - exactly what the 'special' batteries by their peculiar use are intended to prevent."

Is this last sentence really to be taken to mean that field artillery nust take care not to: be effective, so as to remain mobile enough? Are only 'helpless' guns to be in a position to make good the defects of the light guns? I will not pursue these questions farther, but will only remark that every arm which is to be fit for use in field war and able to support field troops must be mobile enough to be able to follow these with certainty. 'That, too, our forefathers knew', and they fulfilled the requirement with their guns of position. But of "special" latteries, as they recommended to be used in the "Year Book," there are no historical counterparts. Now; if I have indicated that under certain conditions I should consider the destruction of the attackiug field artillery by the vertical fire of the defence. possible, I must add that I, nevertheless, think the latter little dangcrons against at well led attack. .

By this I understand that the attacker is carcful not to offer the fixed targets so desirable for the defender's vertical fire, as for instance a field artillery position.

Considering that the vertical fre batteries of the defence are hidden, it 
will be very hard for the attacking field artillery to find suitable positions for itself ; but the advantage for the attacker lies in this, that this difficulty will matter little to him if he has vertical fire batteries at his disposal. If the defender could destroy these, it would be a bad look-out for the attack; fortunately such an event is improbable.

To cstablish this point, I must again remind you of the difference which cxists between the tactical object of the attack and that of the defence.

The one purposes to hold a certain position, the other purposes to drive his enemy out of it; the first offers, on the whole, fixed, the latter moving targets.

With the defence everything is as much as possible prepared, with the attack the arrangements are often not developed till the attack has begun.

It is exactly this last circumstance which forms, I am convinced, tho real $\Lambda$ chilles heel of the defence. If uncertainty can even in ordinary life put one into ia state of the most painful disturbance, this feeling will be heightened in the turmoil of battle.

'The defence is opposed to this uncertainty; it supposes indeed that the attack will proceed in such and such a way, but it knows nothing and will be at least as often nistaken as correct in its suppositions. It is otherwise with the attacker; if he, too, is often enough mistaken, yet it is always something definite, both in purpose and its execution, that is opposed to him by the defence. Howerer much the latter hides itself it can scarcely make itself invisible.

If it neglects the maxim-" First fire, then cover," it transgresses most against itself and will be easily orercome. How dangerous earth works may be to the defence we have already heard; but he who wants to obtain $n$ good fire effect can never withdraw himself entirely from the enemy's view. except in the one case of his using vertical fire. Now it might appenr ver. advantageous for the defender that he should command the whole field with cutirely unseen vertical fire; but it is this uncertainty which might rob these "ostrich" tactics of their result.

If the battalions of the attack are well led-the defence sees nothing of low this happens, and whither it tends, behind what hillock, clump of trees, \&c., they take up their position, and is of ten almost entirely incapable of shelling these positions. I3ut if it really can do so it will probably be much more often possible for the batteries of the attack to effect a sufficient change of position behind their cover than for those of the defence, which perhaps instead of changing their own position keep the original hostile position under fire. On the other liand, the more fixed and longer prepared forms of the whole defence have the effect of enabling the attachers to draw conclusions from what is seen, about that which is not seen; and if he is never secure from false conclusions, any more than the defeuder is secure, yet a correct conclusion on the part of the attack entails much more that is dis. agrecable for the defence than is the case rice versd.

For the defender has already chosen throughout the best position, if therefore he is obliged to alter any part of it, he generally incurs a disadrantage thereby. I do not mean by this to recommend that the vertical fire batteries of the attack should altogether look on the engagement of their hostile sister batteries, as their principal task, especially when they can only engage them with slight probability of hitting. It is much more important that they should remain withdrawn from the enemy's view and be able to destroy those hostile targets, which are sufficiently clearly seen for that purpose; not only will there be no lack of these, but they will be just the factors of the defence which hinder the attack most, and those are not the vertical fire batteries but the gun batteries and the infantry fire.

Vertical fre can only be carried out with ainy prospect of success against 
fixed targzts; horizontal (gun) fire must be used against moving targets. rhat is the reason why cvery defensive position is so well fitted for a mark for vertical fire, while every movement of attack can only be resisted by the "deep" effect of gun fire. When, therefore, the vertical fire of the attack has succeeded in keeping down and shaking the field artillery and infantry of the defence, then it renders possible a forward movenent of the attacking troops. Herein lies the truth that vertical fire is a much more important re. inforcement of the attack than it is of the defence ; and that it is the weapon, by tho just appreciation of which the attack remains the stronger form of vattle. It is, therefore, the attack which, for its initiation and cntire conduct, can less dispense with vertical fire than it can with gun fire (though it must, of course, have the latter to beat back counter-attacks); while, for the defence, to repulse attack, guns are more indispensable than vertical fire pieces. This condition of things is not altered till the attack adopts the forms of the defence, and, conşequently, makes carthworks and occupies positions against the defence (as especially pointed out in the "independent patrols") instead of remaining in motion.

My propositions for attack differ accordingly from the forms used up to date only in so far as they substitute effective vertical fre for gun fire, whereever this latter seens to be the less effective of the two. Thus I sum up my views as follows:-first, thoronghly good intelligence and recomnoitring of the enemy ; opening of the battle by properly led vertical fire batteries; forward movement of the attacking troops (which have been held in readi ness under cover), not till the vertical fire, which has been chichly directea arainst the hostile field artillery and the fortified supporting points of the defence, has had sufficient effect, and thereby all superiority of the hostile horizontal fire-especially at the point which is to be assaulted-has been thoroughly overcome; next, move as near the decisive ranges as the vertical fire allows; then make sure that the defence is suficiently shattered; lastly; assault.

But I must here expressly say that, in spite of its great tactical importance I by no means wish to see rertical fire looked upon as a universal panacea. The attacked can no more think of covering whole battlefields with vertical fire than can the defender; rather it is just he that must be clear on this point, that all dispersion of fre is bad and only concentration of fire is tactically effective. As to this every modern defensive position will offer. enough decisive points to keep the attack from the attempt to fight long thin lines instead of their supporting points.

I do not mind, gentlemen, if this plan of attack reminds you of my reflections on fortress warfare, and impresses it on you that I incidentally treat. the attack in the position-battle just as $I$ do that against fortified points. I willingly profess this view as to the similarity of the two cases, and have convinced myself of its truth since the readoption of vertical fire, and have from that time invariably held it. If it is right, then, you will not consider there is any disadvantage in the fact that the Commander who can win a battle thereby shows how he intends to plant his colours on the works of th eneny.

If you reply by asking me what is going to become of the defence, I can only reply, that I in no wise doubt that it cannot possibly be wiped out from the world by my attack tactics; but that I am convinced it is now the tum of the defence to see that its uses, forms, and means of supyport which do not practically betray its positions and farour the slatterind effect of vertical tire, in cases where it does not seek its remedy in motion, i.e., in well-arranged retreats (as 1812). Concerning the search for new methods of support, I should remind you of the orerwhelming report on the last Inperial manœurres in Hamover.

rOL. XIXY. 
If the defence still scoms to consider the new course, then it will be its own fault if it has cither to yield entirely: to modern attack or cracuate its positions before it, without being able to hold thent with the murderous gun fire, only, of whose invincibility it is so convinced. 'This invincibility will, doubtless, remain, when the attack is weak in vertical fire batteries; but I think the want of these may be ensily supplied. It ought to suffice, nnd to correspond to the earlier historically proved relations between horizontal and vertical fire guns, if one vertical fre battery were allotted to ench brigrade.

'Iurn four companies of the foot artillery regiment of an army corps into as many ficld rertical fire batteries, and the four brigade batteries are ready; one can lardly conceive a simpler reinforcement of the field artillery, nor one more valuable tactically, but it is beyond the scope of our present conference to discuss whether this reinforcement is provided to meet the conditions of our case, and if so, how.

This, however, I mill atlirm, tliat in the next war the attacker, who scoms to make a right use of vertical fire, would challengre his opponent to meet him in prepared positions and to convince him with bloodiest energy of the power of resistanee of the latter. Allow me to add to my modest contribution to tactical science a few words about training.

Years ago, when I gare you my thoughts about fortress warfare, it was urged against me that I demanded abnormal work from the troops, and, above all, their abnormal co-operation. I do not deny that, but I ask you whether the demands I hare inade are greater than the attack itself demands, at any rate greater than its execution at Flevna demanded.

What was the use then of the extraordinary strength in artillery, which the Russians developed, to the attacking infintry l Do you disagree with me becanse I wish to support the infantry by all artillery which can and must relicve it of the preliminary work of attack, without the certainty of which relief the success of the assault secms very doubtful? a preparation which cannot be left to the fire of the attacking infantry, but which must, undoubtedly, be effected by the attacking artillery. "The infantry attack," says Keiw, "which has to advance through artillery fire in its principal stages, has no hope of success; it is by the proper application of vertical fire that the attack can best deliver its infantry from the dangers of such an advance." But how the effect of vertical fire can be estimated in peace inancuvres, seems to me, at any rate; a difficult question to solve. In most cascs a body of troops will not be at all amare of the presence of the vertical fire batteries, from whose murderous fire they are sulfering, and you will see that this is also an advantage for the attack-for you cau practise it-on the sound understanding that the rertical tire, especially in such a case, will have been effective, and hence that the assnult of the infantry will have been thoroughly well prepared. But the defence training is intuch wore difficult to armnge similarly; the troops of the defenco are exposed to a fre of which it is impossible beforeliand to ascertain the resisting force.

The practice ground must naturally show the nature of this fire, as it does that of infautry fire, and its lessons will, of course, not be accepted until the practice gromnd becomes the manocurre ground. But as soon as vertical fire batteries are distributed in these battle practices, as well as the field batteries, the Commanding Officers who attend will have ample opportunity of estinuating the fire effect of the one, as they do of the other.

There, commanders and umpires will very soon get familiar with the effect of vertical fire, although it may be difficult, on account of the great distances at which vertical fire is opened, to estimate its probable ellects on inanouvring troops.

It will be much easier to learn another, not less important, part of the attack of the future thoroughly, viz., reconnaissance of the encmy. That 
alone can keep us from making attacks which may well seem nuch more dangerous with morlern arms thai they were twenty years ago. Who will complain if, instead of these attacks, we have only well-considered and wellprepared assaults? But to arrive at this we must have such a reconnoitring service as can only be learnt by strenuous practice, and for which neither good cyes (or really corresponding ylasses) nor the clearness and quickness of sight, which are indispensable, must be missing.

'The training in co-operation of the different arms will offer no invincible difficulties.

They are, after all, under one command, and though a certain drawing together and mutual understanding may be desirable, where is the difficulty in bringing this abont?

When the infantry and field artillery once know the powerful reinforcement which may be derived from vertical fire, they will not he behindhand in coming forward unreserredly, in order to ensure to themselves the valuable co-operation of the new weapon; and, as the tactical laws which determine the manner in which this weapon co-operates are the simplest imaginable, the requirements of the latter will very soon be intelligently appreciated, and the service of the vertical fire batteries assisted by every sort of intelligence and information.

'The impedimenta inseparable from those batteries will soon be considered real value, and not looked on as ballast; and, of course, the vertical fire batteries will wish to show their thanks by deeds.

In doing so they must think especially of their chief duty, viz., to deserve the confidence reposed in them, by their deeds; they will deserve that best by never endangering their own troops by their fire.

They themselves will seldom be able to see whether the enemy, on which they pour their iron hail, is really crushed by it.

Only the front line of the attacking troops will know this, and must, therefore, take care that the rertical fire is regulated as may be required, and that it censes at the right monent, or is resumed, as the course of the fight requires.

To teach this in peace is, perhaps, more difficult than to practise it in war. Me:mwhile, though it may appenr to require German repose and conscientiousness, German industry, and German thoroughness, to solve all these problems, yet I do not think that, while the motto on our shield stands, any aim will seem to us too high ou account of the difficulties which beset its attaiument. 